\title{
Residual Strength of Carabiners Used by Tree Climbers
}

\author{
Brian Kane and H. Dennis Ryan
}

\begin{abstract}
Tree climbers increasingly use carabiners and apply them in situations for which they are not designed. Because failure of carabiners can result in serious injury or death, the following study tested how well carabiners endure the stress to which climbers subject them. This study distributed carabiners of four types (all manufactured by Petzl) to climbers in Massachusetts and New York, USA, and collected them a year later. Then, carabiners were broken in a universal testing machine and measured the maximum load, as well as surface roughness. No carabiners broke below their rated strength; and used carabiners were, with one exception, as strong as new carabiners. Surface roughness was a weak, but significant, predictor of strength. Findings are discussed in light of climber safety and the importance of conducting long-term studies.

Key Words. Carabiner; Strength; Tree Climbing.
\end{abstract}

In the past two decades, professional tree climbers have adopted and adapted climbing techniques and gear from other high-angle rope disciplines. These techniques and gear may improve efficiency and/or safety. However, without proper understanding of a new technique or piece of equipment, particularly the limitations on it, the consequences can be dire, as a recent injury demonstrates (Laver 2008). One piece of gear that has become more popular among climbers is the carabiner, which is used to attach ropes, split-tails, and lanyards to a saddle. While the carabiner has gained support among climbers and is frequently described in trade publications (Oxman 2001, Adams 2004, Dunlap 2004) it was not initially designed for use in the tree care industry (Blair 1995).

Carabiners have been used for many years in various highangle rope disciplines such as caving, rock climbing, and mountaineering (Blair 1995). Having undergone changes in shape and material, most carabiners used by rock climbers are made of aluminum alloy to maximize the strength-to-weight ratio. One advantage of carabiners is that they can easily accept rope by opening the gate, which allows the use of eye-and-eye spliced split-tails for tying one of the newer friction hitches (Adams 2004).

The American National Standard for Arboricultural Operations-Pruning, Repairing, Maintaining, and Removing Trees, and Cutting Brush-Safety Requirements [ANSI Z.133 (Anonymous 2006)] permits the use of carabiners for climbing, as long as they meet two requirements. First, carabiners used in tree climbing must be positive locking, which means that a climber must perform two separate actions prior to opening the gate. Second, carabiners must meet the minimum tensile strength for traditional steel rope snaps [22.24 kN (5,000 lbf)] (Anonymous 2006). Even with these two conditions, there are important limitations to use of carabiners for climbing. For example, carabiners only meet the ANSI Z.133 minimum strength requirements when loaded along the spine and when the gate is closed.

In light of their adoption into a discipline for which they were not designed, as well as the taxing conditions to which climbers subject their gear, our objectives were to determine the durability of carabiners used in professional tree climbing, and assess any visual and operational cues that could indicate diminished performance.

\section{METHODS}

In the spring 2006, we distributed aluminum carabiners of four types to climbers from five tree care companies in Massachusetts and New York, USA. Three or four additional carabiners of each type were stored in a cabinet as controls. All carabiners were manufactured by Petzl (Clearfield, UT, USA), and were categorized by shape (Am'D and William) and gate mechanism (Ball-Lock and Tri-Act). We asked climbers to provide the following information: type of saddle, type of attachment knot for climbing line and split-tail, type of climbing line, and type of split-tail. We also asked climbers to record the number of hours climbed each day and to consistently use the same carabiners for their climbing line and split-tail.

Approximately one year later, climbers returned the carabiners, which we visually inspected for damage and tested for normal gate operation. Too few climbers recorded the number of hours climbed, so we measured surface roughness as a surrogate, assuming that it reflected the amount and/or intensity of use. We measured surface roughness with a profilometer (Model 3800, Starrett Machine Co., Athol, MA), taking five measurements on the same spot of each carabiner, and using the mean value in the analysis.

We placed carabiners in a universal testing machine $[133 \mathrm{kN}$ ( 30,000 lbf) capacity, accurate to $0.1 \%$; MTS, Eden Prairie, MN], and tested them roughly in accordance with the F1774 standard (Anonymous 1999). In contrast to the F1774 standard, we used galvanized steel shackles [19.8 $\mathrm{mm}$ (0.78 in) diameter] instead of steel dowels [10 $\pm 0.1 \mathrm{~mm}$ (0.0039 in) diameter] to attach carabiners to the testing machine. We used the shackles primarily out of convenience given the existing set-up of the testing machine. All carabiners were loaded along the spine, as required by the standard, although the larger diameter shackle would cause a greater bending moment to be applied to the carabiners. This would, if anything, reduce the breaking strength of the carabiner, and the bias applied equally to all carabiners. The larger diameter shackles more likely mimicked the loading during tree climbing since climbing lines can be $14 \mathrm{~mm}$ ( 0.55 in) in diameter, and often girth-hitched, which doubles the rope diameter where it attaches to the carabiner. When tied in a friction hitch, eye-and-eye spliced split-tails extend $16-20 \mathrm{~mm}(0.63-0.79 \mathrm{in})$ from the spine of the carabiner. 
The testing machine applied an increasing tensile load at $0.5 \mathrm{~mm} / \mathrm{s}(0.02 \mathrm{in} / \mathrm{s})$, recording loads at $10 \mathrm{~Hz}$. We photographed failed carabiners and categorized them according to the location of failure: barrel, body, hinge or key (Figure 1). Since Am'D and William carabiners have different strength ratings, we also calculated the relative breaking strength $(\Delta \mathrm{P})$ :

$$
\Delta \mathrm{P}=\left|\mathrm{P}_{\text {MAX }}-\mathrm{P}_{\text {RATED }}\right| / \mathrm{P}_{\text {RATED }}
$$

where $\mathrm{P}_{\text {MAX }}$ and $\mathrm{P}_{\text {RATED }}$ are the breaking strength and rated strength, respectively.

We used the Kolmogorov-Smirnov test to confirm that data were normally distributed, with the exception of surface roughness measurements for Am'D Ball-Lock carabiners. For comparisons involving that variable, we used the nonparametric Wilcoxon's signed rank test to test hypotheses. We used a t-test to compare breaking strength, relative breaking strength, and surface roughness between new and used carabiners of each type, after confirming homogeneity of variance within each comparison by Levene's test. We used one- and two-way analyses of variance (ANOVA) to compare the response variables listed above between failure types and carabiner types (classified by condition), respectively. Where appropriate, we used Tukey's honestly significant difference to test multiple comparisons within each ANOVA. We used regression analysis to investigate the effect of surface roughness on breaking strength.

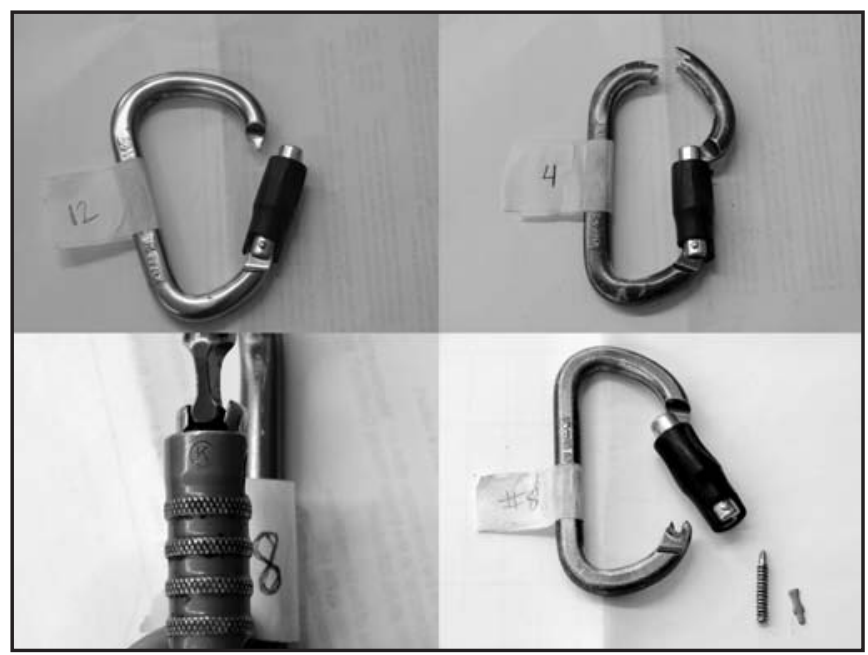

Figure 1. Types of failure of carabiners (clockwise from upper left): key, body, hinge, barrel.

\section{RESULTS}

No carabiner failed below its rated strength, and all exceeded the ANSI Z.133 minimum strength by at least $4.0 \mathrm{kN}$ (899 lbf). Used carabiners were as strong as new carabiners for each type except William Ball-Lock, for which there was some evidence that new carabiners were stronger (Table 1). Used Am'D BallLock carabiners exhibited the smallest relative breaking strength, but were still nearly $10 \%$ stronger than rated (Table 1). Am'D carabiners were stronger than William carabiners, both new and used (Table 1). The relative breaking strength, however, was greater for new William carabiners than new Am'D carabiners (Table 1). There was some evidence of this difference for used Am'D and William carabiners (Table 1). Tri-Act and Ball-Lock carabiners were equally strong when new, but used Tri-Act carabiners were stronger than used Ball-Lock carabiners (Table 1). Tri-Act and Ball-Lock carabiners had similar relative breaking strengths when new, but when used, Tri-Act carabiners had greater relative breaking strength than Ball-Lock carabiners (Table 1). There was some evidence that the breaking strength of barrel failures was greater than that of key failures (Table 2), but the relative breaking strength was similar for all failure types.

Breaking strength diminished somewhat with increasing surface roughness, but the relationship was weak (Figure 2). The scatter plot revealed wide variation in roughness for used carabiners, with roughness values for new carabiners fitting inside that range (Figure 2). Surface roughness did not differ for any comparisons of carabiners (by condition, shape or gate), with the exception that Tri-Act carabiners had marginally less rough surfaces than Ball-Lock carabiners when new (Table 2). Visual inspection did not reveal any extraordinary defects, aside from three carabiners that had gates that were "sticky" and did not close properly. The breaking strength of these carabiners was not different from the mean breaking strength of the matching type of carabiner for each, but they were all Ball-Lock gates. Surface roughness of body failures was greater than barrel failures (Table 2) but there were no other differences among failure types.

\section{DISCUSSION}

Given their current popularity, carabiners will likely continue to used by tree climbers. Thus, two findings in particular were reassuring. First, used carabiners were, with one exception, as strong as new ones. Second, normal wear and tear (reflected by surface roughness) was only a weak predictor of breaking strength. In both cases, however, the small sample size limits the ability to generalize these conclusions. The F1774 standard (Anonymous 1999) requires a minimum of 5 replicates of each test, which was not achieved for all carabiner types tested. This lack of conformity may not be critical in light of the relatively small variability in the results (the mean coefficient of variation was less than $4 \%$ for breaking strength, and it was similar among carabiner types and condition). The conclusions are also limited with respect to time, since many climbers use carabiners for more than one year. Collecting longer-term data would be helpful in future investigations, especially considering that Petzl offers a three-year warranty on the carabiners tested. A final limitation is that the climbers come from a potentially biased sample, in that they all worked for companies staffed with certified arborists as well as safety programs.

Since only three carabiners from the present study had gates that stuck, it is unclear whether gate mechanisms lose functionality before the inherent strength of the carabiner is undermined to the point of danger. Loaded when the gate is open, carabiners are typically about one-fourth as strong as when the gate is closed. A faulty carabiner loaded with the gate open is a more likely source of strength reduction than normal wear and tear. One reasonably expects that a climber would retire a carabiner if the gate no longer functioned properly, but Statham and Roebuck (2004) observed several climbers using carabiners with faulty gates. They speculated that carabiners were being 
Table 1. Means (SE's in parentheses) for relative breaking strength ${ }^{2}$, breaking strength, and surface roughness of carabiners. For each comparison, read down a column, means followed by the same letter are not different $(P>0.05)$.

\begin{tabular}{|c|c|c|c|c|c|c|}
\hline Shape & Gate & Condition & $\mathrm{N}$ & $\begin{array}{l}\text { Relative } \\
\text { Breaking } \\
\text { Strength }(\%)\end{array}$ & $\begin{array}{l}\text { Breaking } \\
\text { Strength }(k N)\end{array}$ & $\begin{array}{l}\text { Surface } \\
\text { Roughness } \\
(\mathrm{mm})\end{array}$ \\
\hline Am'D & Ball-Lock & New & 4 & 13.8 (1.79) a & $31.88(0.50) \mathrm{a}$ & $0.73(0.04) \mathrm{a}$ \\
\hline Am'D & Ball-Lock & Used & 4 & $9.40(3.54) \mathrm{a}$ & $30.63(0.99) \mathrm{a}$ & $0.84(0.25) \mathrm{a}$ \\
\hline Am'D & Tri-Act & New & 4 & $15.8(2.61) \mathrm{a}$ & $32.43(0.73) \mathrm{a}$ & $0.64(0.05) \mathrm{a}$ \\
\hline Am'D & Tri-Act & Used & 6 & $13.7(1.45) \mathrm{a}$ & $31.83(0.40) \mathrm{a}$ & $0.52(0.10) \mathrm{a}$ \\
\hline William & Ball-Lock & New & 3 & $17.7(1.73) \mathrm{a}$ & $29.43(0.43) \mathrm{a}$ & $0.85(0.07) \mathrm{a}$ \\
\hline William & Ball-Lock & Used & 6 & $12.1(1.56) b^{y}$ & $28.02(0.39) b^{y}$ & $0.86(0.13) \mathrm{a}$ \\
\hline William & Tri-Act & New & 5 & $21.8(1.72) \mathrm{a}$ & $30.46(0.43) \mathrm{a}$ & $0.69(0.05) \mathrm{a}$ \\
\hline William & Tri-Act & Used & 5 & $19.3(2.01) \mathrm{a}$ & $29.82(0.50) \mathrm{a}$ & $0.83(0.17) \mathrm{a}$ \\
\hline Am'D & - & New & 8 & $14.8(1.51) \mathrm{a}$ & $32.15(0.42) \mathrm{a}$ & $0.68(0.03) \mathrm{a}$ \\
\hline William & - & New & 8 & 20.3 (1.39) b & $30.08(0.35) b$ & $0.75(0.05) \mathrm{a}$ \\
\hline William & - & Used & 11 & $15.3(1.64) b^{x}$ & $28.84(0.41) b$ & $0.84(0.10) \mathrm{a}$ \\
\hline - & Ball-Lock & New & 7 & $15.5(1.40) \mathrm{a}$ & $30.83(0.59) \mathrm{a}$ & $0.78(0.04) \mathrm{a}$ \\
\hline - & Tri-Act & New & 9 & $19.2(1.76) \mathrm{a}$ & $31.33(0.51) \mathrm{a}$ & $0.67(0.04) b$ \\
\hline - & Ball-Lock & Used & 10 & $11.0(1.63) \mathrm{a}$ & $29.06(0.60) \mathrm{a}$ & $0.85(0.12) \mathrm{a}$ \\
\hline - & Tri-Act & Used & 11 & $16.2(1.44) \mathrm{b}$ & $30.92(0.44) b$ & $0.66(0.10) \mathrm{a}$ \\
\hline
\end{tabular}

${ }^{2}$ see equation 1

$P=0.0614$

${ }^{x} P=0.0599$

Table 2. Means (SE's in parentheses) for relative breaking strength ${ }^{2}$, breaking strength, and surface roughness. Read down a column, means followed by the same letter are not different $(P>0.05)$.

\begin{tabular}{lllll}
\hline $\begin{array}{l}\text { Failure } \\
\text { Type }\end{array}$ & $\mathrm{N}$ & $\begin{array}{l}\text { Relative } \\
\text { Breaking } \\
\text { Strength }(\%)\end{array}$ & $\begin{array}{l}\text { Breaking } \\
\text { Strength }(\mathrm{kN})\end{array}$ & $\begin{array}{l}\text { Surface } \\
\text { Roughness } \\
(\mathrm{mm})\end{array}$ \\
\hline Barrel & 11 & $15.9(1.58) \mathrm{a}$ & $31.46(0.41) \mathrm{a}$ & $0.57(0.05) \mathrm{a}$ \\
Body & 6 & $13.7(1.07) \mathrm{a}$ & $29.57(0.76) \mathrm{ab}$ & $0.89(0.09) \mathrm{b}$ \\
Hinge & 6 & $11.3(2.68) \mathrm{a}$ & $31.15(0.75) \mathrm{ab}$ & $0.83(0.15) \mathrm{ab}$ \\
Key & 14 & $17.5(1.48) \mathrm{a}$ & $29.86(0.47) \mathrm{b}^{\mathrm{y}}$ & $0.76(0.08) \mathrm{ab}$ \\
\hline
\end{tabular}

${ }^{\mathrm{z}}$ see equation 1

$$
{ }^{y} P=0.0551
$$

used beyond the manufacturers' expected service life (although that particular length of time is not clear). Even when the gate is open, however, the rated strength of carabiners in the present study was $7 \mathrm{kN}$ (1574 lbf). The greater danger associated with an open gate may be the climber being detached from his rope or saddle, as has occurred in rappelling (McMillan 1998). Future studies should examine the length of service carabiners typically endure, and what motivates climbers to retire carabiners.

Am'D carabiners were expected to have a greater breaking strength, since they are rated $3 \mathrm{kN}$ (674 lbf) stronger than William carabiners. The latter were designed to accept more than one attachment point, and have an asymmetrical shape. This presumably accounts for its lower rated strength, while its greater relative breaking strength (compared to an Am'D carabiner) may be due to William carabiners being designed with a greater safety factor to accommodate multiple attachments. As an attachment loads the carabiner farther from the spine, the resultant force increasingly bends the carabiner, as opposed to loading purely in tension, for which the carabiner is strongest. The absence of a difference in relative breaking strength between used Am'D and William carabiners may reflect a greater tendency of William carabiners to endure bending if the carabiner moves relative to the attachment points on the saddle and rope, as some climbers observed. Depending on the type of saddle, split-tail, and attachment knot, the greater width of William carabiners facilitates twisting moments as the carabiner moves relative to its attachment points and other hardware. For example, when two carabiners are attached to the 'bridge' of a saddle (e.g., Glide or Butterfly saddles) and the climber rotates to one side, a D- or

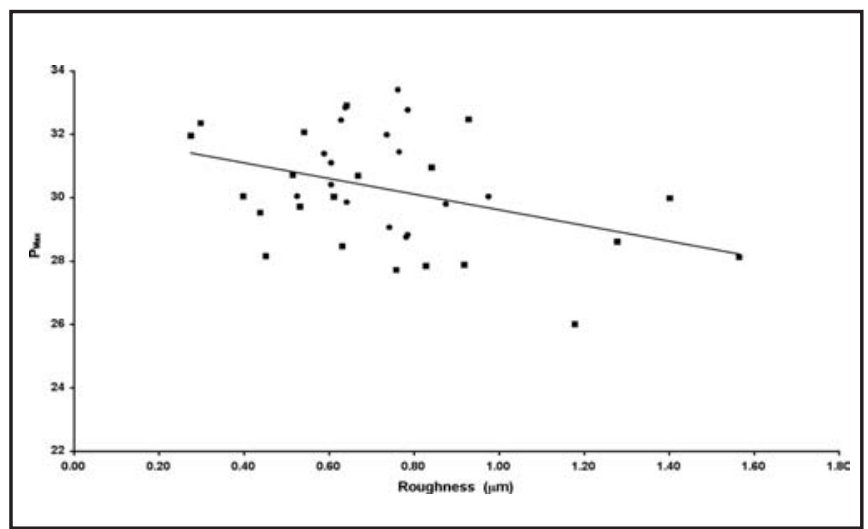

Figure 2. Scatter plot and best-fit line for the relationship between breaking strength $\left(\mathrm{P}_{\text {MAX }}\right)$ and surface roughness $(\rho)$ of new $(\Theta)$ and used $(\square)$ carabiners. The prediction equation, $\mathrm{P}_{\text {MAX }}=32.33-2.49 \rho$, was weak $\left(r^{2}=0.15\right)$ but the intercept $(P<0.0001)$ and regression coefficient $(P=0.0185)$ were both significant. The minimum value of the ordinate corresponds to the minimum breaking strength of hardware (22.24 kN) set forth in the Z.133 (Anonymous 2006). 
pear-shaped carabiner can fit into the wide opening of a William carabiner. As the climber returns to face forward, the inserted carabiner can impart a torque that attempts to rotate the William carabiner about its long axis. Popall (2003) observed a figure-eight-induced torque break the barrel of carabiners.

It was unclear why used, but not new, Ball-Lock carabiners were not as strong, in both the absolute and relative comparisons, as Tri-Act carabiners. This did not appear to be related to the observation that all three carabiners with sticky gates were Ball-Lock carabiners, because among Ball-Lock carabiners, the mean strength of those with sticky gates was similar to the remainder. During the study, Petzl released a new design of the Ball-Lock gate, so this particular finding may no longer apply.

Differences in breaking strength among failure types were also unclear, especially since they were inconsistent with differences in surface roughness among failure types. The small number of body failures contradicted findings of Blair et al. (2005) for which all failures were of the body. Since the carabiners and test methods differed between the two studies, we can only speculate whether the limited number of body failures was due to the more complex gate mechanisms of carabiners used in the present study. It is possible that attaching carabiners to a saddle with steel D-rings caused repeated point loading that encouraged body failures, as observed by McKently et al. (2003). In contrast to the McKently et al. (2003) study, we did not observe obvious gouges in carabiners that experienced body failures. Since too few climbers indicated the type of saddle they used, it was not possible to speculate whether point loading may have led to body failures.

It seems rather unlikely that climbers would be able to predict strength loss by even a careful visual examination of carabiners, unless severe defects existed [e.g., the gouges reported by McKently et al. (2003)]. Petzl's inspection form lists the following defects that should be checked for during a visual inspection: cracks, marks, deformation, wear, corrosion. Of these, wear seems to be a less reliable indicator, in light of the weak prediction of strength from surface roughness. We observed wear and marks on all of the used carabiners, but were not able to identify particularly worn carabiners. Blair et al. (2005) similarly doubted the ability to predict retirement of carabiners based on visual cues of incipient failure. It is easy to imagine improper loading that would weaken a carabiner but not impart any obvious surface wear. Since it is difficult to avoid entirely improperly loading carabiners during climbing, we reiterate the importance of future studies to investigate longer-term use, as well as use by a greater variety of climbers.

Using cycles-to-failure data from Blair et al. (2005), and assuming that a $90 \mathrm{~kg}(198 \mathrm{lb})$ tree climber who falls $1.5 \mathrm{~m}(4.92$ $\mathrm{ft}$ ) endures approximately $5 \mathrm{kN}(1124 \mathrm{lbf})$ of force (Carpenter
2008), a climber could still take more than 3,000 falls before causing failure of the carabiner. [The rated strength of the carabiners tested by Blair et al. (2005) was $24 \mathrm{kN}(5,395 \mathrm{lbf})$.] Doubling the fall distance for the $90 \mathrm{~kg}$ climber would still require 238 falls to break one of the carabiners Blair et al. (2005) tested. A climber would likely suffer bodily injury long before taking so many falls. Thus, ordinary wear for a year would not likely reduce strength to the point where a climber would risk breaking a carabiner.

Although not included in the analysis because they were of different manufacturers, shapes, and gates, we also tested four carabiners nearly ten years old; each had endured at least three years of daily climbing. None failed below its rated strength, and all appeared to be much more worn than the carabiners used for a single year. Neither these carabiners, nor those analyzed in the study showed any signs of deformation prior to testing. Thus, even longer term "normal" use seems unlikely to cause dangerously damaging wear, unless an obvious defect is present, or the gate does not close properly.

The lack of participation and follow-through among climbers was disappointing. Of 41 carabiners distributed, only 21 were returned, and of these, only 12 had usable hours recorded ( 2 each from 6 individuals). The project originally intended to analyze strength change in rope snaps as well as carabiners, but of fourteen rope snaps that were distributed, only one was returned. Equally disappointing was the apparent lack of general interest in participating in the project. Although many companies initially expressed an interest, only five companies actually participated. Ultimately, only four companies were represented, because no carabiners or snaps were returned from one company. In hindsight, offering participants an additional incentive, beyond the carabiners and rope snaps each participant received may have increased participation.

\section{CONCLUSIONS}

Carabiners used for a year by climbers were, in general, as strong as new carabiners. Regardless of differences among gate types and shapes for new and used carabiners, none of them broke at less than their rated strength. Neither of these findings, however, should be interpreted to mean that carabiners do not have to be inspected or are safe to use for a year under any conditions. Climbers must take great care inspecting carabiners, especially with respect to proper functioning of the gate mechanism. Additional testing should be undertaken to address limitations of the present study, including small sample sizes, short duration of carabiner use, and the presumed better treatment of carabiners by knowledgeable, experienced, and safety-conscious climbers. 
Acknowledgments. We gratefully acknowledge all the climbers who participated in the project, especially the safety and training representatives who organized the distribution of carabiners for their coworkers: Dane Buell (SavATree), Ed Carpenter (Hartney-Greymont), Bruce Duffy

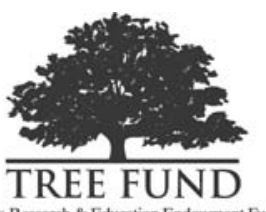
(Tree Specialists), and Jason Ford (The Tree Wizard). We also thank Marcy Gladdys (University of Massachusetts-Amherst) for assisting with data collection and two anonymous reviewers who offered helpful suggestions to earlier drafts of the manuscript. This study was supported in part by a Hyland Johns grant from the TREE Fund.

\section{LITERATURE CITED}

Adams, M. 2004. An overview of climbing hitches. Arborist News 13(5):29-35.

Anonymous. 1999. Standard Specification for climbing and Mountaineering Carabineers. American Society for Testing and Materials. West Conshohocken, PA 5 pp.

Anonymous. 2006. American National Standard for Arboricultural Operations-Pruning, Repairing, Maintaining, and Removing Trees, and Cutting Brush-Safety Requirements. American National Standards Institute NY, NY 32 pp.

Blair, D.F. 1995. Arborist Equipment: A Guide to the Tools and Equipment of Tree Maintenance and Removal. ISA, Champaign, IL 291 pp.

Blair, K.B., D. Custer, J. Graham, and M. Okal. 2005. Analysis of fatigue failure in D-shaped karabiners. Sports Engineering 8:107-113.

Carpenter, E. 2008. Unpublished data from drop tests at Bristol County Agricultural High School, Dighton, MA.

Dunlap, T. 2004. Have more fun using progressive arboricultural techniques. TCI 15(1):32-36.

Laver, A. 2008. Wilton Square. Treeline: ISA UK \& I Chapter magazine. July 2008. <http://www.isa-arboriculture.org/content/cm000181.htm>.

McKently, J.B. Parker, and C. Smith. 2003. "Point loading" aluminum carabiners, a cause for concern? International Technical Rescue Symposium. Salt Lake City, UT 14 pp.

McMillan, N. 1998. Abseiling and belaying accidents with a figureof-eight. Incident Ref. 97/3/C.Pol British Mountaineering Council, Manchester, England. 7pp.

Oxman, M. 2001. Gearing up. Arbor Age 21(5):24-26.

Popall, P. 2003. A little something you should know about carabiners. International Technical Rescue Symposium. Salt Lake City, UT 4 pp.

Statham, J. and B. Roebuck. 2004. Karabiner Safety in the Arboriculture Industry. Health \& Safety Laboratory HSL/2003/18 33 pp.

Brian Kane (corresponding author)

University of Massachusetts - NRC

126 Holdsworth Hall

Amherst, MA 01003, U.S.

H. Dennis Ryan

University of Massachusetts - NRC

119 Holdsworth Hall

Amherst, MA 01003, U.S.
Résumé. Les élagueurs utilisent de plus en plus des mousquetons, une application pour laquelle les mousquetons n'ont pas été conçus. Du fait que le bris de mousquetons peut provoquer des blessures sérieuses ou la mort, nous avons alors testés jusqu'à quel point les mousquetons peuvent supporter le stress auquel ils sont soumis par les élagueurs. Nous avons distribués quatre types de mousquetons (tous manufacturés par Petzl) à des élagueurs du Massachussetts et du New York et les avons par la suite récupérés un an plus tard. Nous avons brisés les mousquetons au moyen d'une machine universelle d'essai et avons mesuré la charge maximale tout comme la rugosité de la surface. Aucun mousqueton ne s'est brisé en deçà de sa résistance nominale et les mousquetons usagés étaient, sauf une exception, aussi forts que les mousquetons neufs. La rugosité de la surface constituait une faible, mais tout de même significative, variable de prédiction de la résistance. Nous discutons de nos découvertes à la lumière de la sécurité de l'élagueur et de l'importance de mener des études à long terme.

Zusammenfassung. Baumkletterer benutzen vermehrt Karabiner für Einsätze, für welche Karabiner nicht konzipiert wurden. Da das Versagen von Karabinern zu Verletzungen oder Tod führen kann, testeten wir, wie gut Karabiner den Anforderungen, welchen sie ausgesetzt werden, standhalten. Wir verteilten vier Karabiner-Typen (alle von Petzl) an Kletterer in Massachusetts und New York und sammelten sie ein Jahr später wieder ein. Wir brachen die Karabiner in einer universellen Prüfmaschine und haben die maximale Last, sowie die Rauheit der Oberfläche gemessen. Kein Karabiner brach unter der vom Hersteller angegebenen Last und die gebrauchten Karabiner waren mit einer Ausnahme so stark wie neue Karabiner. Die Oberflächenrauheit war eine schwacher, aber signifikanter Hinweis auf die Stärke. Wir diskutieren unsere Ergebnisse im Licht der Kletterersicherheit und der Bedeutung von Langzeitstudien.

Resumen. Los trepadores de árboles están incrementando el uso de los mosquetones, una aplicación para la cual éstos no fueron diseñados. Debido a que su falla puede resultar en serias lesiones o muerte, probamos qué tanto los mosquetones soportan el esfuerzo al cual los trepadores los someten. Distribuimos mosquetones de cuatro tipos (todos manufacturados por Petzl) a trepadores en Massachusetts y New York, USA, y los recogimos un año después. Rompimos los mosquetones en máquinas de prueba universal y medimos la carga máxima, como también la rugosidad superficial. Ninguno de los mosquetones rompió debajo de su resistencia indicada, y los mosquetones usados fueron, con una excepción, tan fuertes como los nuevos. La rugosidad superficial fue débil pero significante para predecir la resistencia. Discutimos nuestros hallazgos a la luz de la seguridad del trepador y la importancia de la conducción de estudios a largo plazo. 